\title{
ЕЛЕКТРОННЕ НАВЧАЛЬНЕ ВИДАННЯ ЯК НОВИЙ ФОРМАТ ЗАБЕЗПЕЧЕННЯ НАВЧАЛЬНОГО ПРОЦЕСУ У ЗАКЛАДАХ ВИЩОЇ ОСВІТИ
}

\section{М. В. Бігдан, Р. М. Кантемирова, О. В. Кондрашова, О. Л. Резніченко}

Кременчуцький національний університет імені Михайла Остроградського

вул. Першотравнева, 20, м. Кременчук, 39600, Україна. E-mail: kantemyrovarm@gmail.com

Досліджено особливості електронного навчального видання як різновиду сучасних навчальних видань для закладів вищої освіти, проаналізовано видання електронної навчальної літератури для закладів вищої освіти в Україні, висвітлено проблеми і передумови розвитку електронних навчальних видань для 3ВО на сучасному етапі та стан цього питання у сьогоденні. Доведено необхідність системного і комплексного дослідження сучасних електронних навчальних видань для закладів вищої освіти, їх функціональні особливості, специфіка оформлення, вимоги до структури та змісту електронних навчальних видань для закладів вищої освіти та умови їх реалізації. Зроблено спробу провести комплексне дослідження сучасних електронних навчальних видань для вищих навчальних закладів. 3'ясовано значення навчального видання для ЗВО як інформативно-методичного засобу навчання, охарактеризовано типологічні різновиди навчальних видань для закладів вищої освіти.

Ключові слова: навчальні видання, електронне навчальне видання, заклади вищої освіти, електронні освітні ресурси (ЕОР).

\section{ЭЛЕКТРОННОЕ УЧЕБНОЕ ИЗДАНИЕ КАК НОВЫЙ ФОРМАТ ОБЕСПЕЧЕНИЯ УЧЕБНОГО ПРОЩЕССА В ЗАВЕДЕНИЯХ ВЫСШЕГО ОБРАЗОВАНИЯ}

М. В. Бигдан, Р.М. Кантемирова, О. В. Кондрашова, О.Л. Резниченко

Кременчугский национальный университет имени Михаила Остроградского

ул. Первомайская, 20, г. Кременчуг, 39600, Украина. E-mail: kantemyrovarm@gmail.com

Исследованы особенности электронного учебного издания как разновидности современных учебных изданий для заведений высшего образования, проанализированы издания учебной литературы для заведений высшего образования в Украине, выявлены проблемы и предпосылки развития учебных изданий для заведений высшего образования на современном этапе и состояние этого вопроса в настоящем. Доказана необходимость системного и комплексного исследования современных электронных учебных изданий для заведений высшего образования, их функциональные особенности, специфика оформления, требования к структуре и содержанию электронных учебных изданий для заведений высшего образования и русловий их реализации. Предпринята попытка провести комплексное исследование современных электронных учебных изданий для заведений высшего образования. Выяснено значение учебного издания для заведений высшего образования как информационно-методического средства обучения, охарактеризованы типологические разновидности учебных изданий для заведений высшего образования.

Ключевые слова: учебные издания, электронное учебное издание, заведение высшего образования, электронные образовательные ресурсы (ЭОР).

АКТУАЛЬНІСТЬ РОБОТИ. Книга була і надалі залишається одним 3 найбільших надбань людства за всю його історію, адже вона є невичерпним джерелом різного роду інформації, засобом передачі життєвого та професійного досвіду, способом виразити свої думки та передати почуття. 3 давніх часів книга у своїх первинних формах мала важливе інформаційне, емоційне, дидактичне значення.

Історичні витоки навчальних видань сягають сивої давнини, коли наукові знання фіксувалися на первинному видавничому матеріалі. Навчальні видання пройшли складний шлях від написів на глиняних табличках у так званій «глиняній бібліотеці» ассирійського правителя Ашшурбаніпала, що датується 600-тими роками до нашої ери, де містилися таблички з текстами різнопланової наукової тематика (медичної, релігійної, історичної), через кам'яні плити Ляонеської академії у Китаї, шовкові та пергаменті сувої Індії та Близького Сходу до таких звичних для нас паперових підручників. Прогрес неминучий, тож, сучасна освіта і наука, так само, як і цільова аудиторія цих видань, вимагають новітніх засобів навчання.

Дана робота має на меті дослідження особливостей електронного навчального видання як різновиду сучасних навчальних видань для закладів вищої освіти, аналіз видання навчальної літератури для закладів вищої освіти в Україні, проблеми і передумови розвитку електронних навчальних видань для ЗВО на сучасному етапі. Під час дослідження загальнонаукові методи використовувалися, серед яких аналіз, синтез, узагальнення, порівняння тощо.

МАТЕРІАЛ І РЕЗУЛЬТАТИ ДОСЛІДЖЕНЬ. Навчальна література розглядається як об'єкт, який одночасно є носієм змісту освіти, формою фіксації їі різних елементів і проектом навчального процесу. Саме навчальна література $\epsilon$ тією органічною єдністю, через яку реалізується процес навчання [1]. Тож створення якісних сучасних підручників, посібників, довідників, словників є запорукою якісної освіти. Науковці впевнені, що модернізація вищої освіти тісно пов'язана 3 розвитком саме україномовного видання навчальної літератури [2]. Підготовка підручника або навчального посібника є логічним підсумком творчої діяльності науковця або викладача вищого навчального закладу з розробки поточних програмно-методичних та навчально-методичних матеріалів. Створення навчально-методичного забезпечення інноваційного типу набуває особливого значення у період модернізації вищої освіти та іï 
інтеграції у світовий науковий простір. За умови збільшення кількості інтерактивних форм проведення занять (від 20 до 40\% часу аудиторних занять), підвищується роль навчальних видань як засобів посилення креативного характеру та трудомісткості самостійної роботи студентів за умови скорочення обсягу аудиторних занять. У таких умовах постає потреба у забезпеченні студента достатньою кількістю навчальної літератури як для аудиторних занять, так і для самостійної роботи, задля забезпечення високої якості підготовки [1]. Дослідники наголошують на тому факті, що успіх позааудиторної роботи студентів та рівень творчого засвоєння змісту дисциплін безпосередньо залежить від якості та різноманіття начальних та навчально-методичних видань, що їм запропоновано [1]. Так, переважна більшість світових дослідників процесу навчання та його удосконалення наголошують на провідній ролі електронних навчальних видань як одному із засобів підвищення якості навчання [3], перевага яких полягає також у значно нижчий ціні у порівнянні з паперовим варіантом та зручністю у використанні [4].

Водночас, українські фахівці наголошують на проблемі випуску навчальної літератури для вишів, що пов'язана, в першу чергу, з вирішенням комплексу питань соціального, економічного, культурноосвітнього характеру, адже випуск та поширення навчальної книги для вищої школи потребує системного менеджменту та маркетингу [4]. Видання навчальної та наукової книги має свої особливості складніше набір та верстка (формули, графіки, схеми, таблиці тощо), коректура та редагування (термінологія), невеликі тиражі, нерентабельна діяльність та інше. Сучасне навчальне видання висуває певний ряд вимог до авторів, адже навчальне видання - це специфічна література, що має свої особливості, зумовлені функціями, що вони їх виконують.

Структура й зміст предметної галузі навчальних видань мають своєрідний характер, адже включені не тільки знання, а й методи їх отримання, не тільки уявлення й навички, але й методи їх практичного використання. Предметна галузь видань забезпечує виконання ряду функцій, властивих навчальній літературі.

Специфіка сучасного навчального видання зумовлена також їх функціональним навантаженням. Відомо, що начальне видання виконує багато функцій, але найважливішими 3 них $є$ інформаційна, пізнавальна і виховна. Так, інформаційна функція спрямована перш за все на формування інформаційної культури студентів, при цьому обсяг фактичного матеріалу має бути достатнім задля досягнення мети. Пізнавальна функція має на меті розгляд науково-предметного матеріалу, а саме основи науки, фундаментальних знань, актуальних питань. Саме відображення цих функцій забезпечує реалізацію професійної компоненти навчального матеріалу. Виховна функція навчального видання полягає у реалізації завдань навчання, що сприяють розвиткові особистості, становленню наукового світогляду та громадянської відповідальності.
Рівень забезпечення навчальною літературою вкрай низький і становить за найменуванням близько 6\%, а за кількістю примірників - 9\% [6]. Випуск навчальної літератури поставлений у нашій країні на наукову основу, він здійснюється на базі перспективного планування усіх видів і форм навчання. Безпосередньо видання навчальної літератури, враховуючи іiі специфіку, також має свої особливості. Виданням навчальної літератури займаються видавничі організації різних форм власності, такі як «Академія», «Академвидав», «Вища школа», «Техніка», «Либідь», «Знання», «Кондор», «Центр навчальної літератури», «Вікар». Провідні заклади вищої освіти також мають свої досить потужні видавничі центри, що забезпечують студентів та викладачів і усіх зацікавлених осіб навчальними виданнями різних галузей науки. Серед них слід звернути увагу на наступні: Видавничій дім «КиєвоМогилянська академія», «МАУП», «Видавництво Свропейського університету», «Політехніка», «Україна», «КНЕУ», «Львівська політехніка», «Університетська книга». Зазначені видавничі організації спеціалізуються на випуску підручників та навчальних посібників для вищої школи переважно гуманітарного спрямування, навчальні видання з природничо-технічної сфери представлені у незначній кількості.

У видавничій практиці склалася вертикальна структура управління випуском навчальної літератури. Формально нині діє трирівнева система менеджменту, до якої входять такі суб'єкти, як Міністерство освіти і науки України, видавничі організації, підприємства книгорозповсюдження. До складу суб'єктів ринку також входять індивідуальні та колективні покупці. Оскільки розглядається книжковий ринок, а саме сегмент навчальної літератури для вищої школи, основними покупцями є студенти, аспіранти та викладачі, заклади вищої освіти та бібліотеки [4].

Освіта наразі знаходиться в складній ситуації, що спричинена поглибленням фундаментальних суперечностей між традиційними методами і темпами навчання та обсягом інформації, що постійно зростає. Так, обсяг знань, необхідний для випускників технічних спеціальностей ЗВО, подвоюється кожні три-чотири роки, у той час, як ще у першій половині XX століття цей період становив близька 30 років. У такій ситуації все більшого значення набувають технології електронного та дистанційного навчання, що дозволяють засвоювати матеріал на 40-60\% швидше [7].

Початок XXI століття став початком масового виробництва програмних продуктів освітнього характеру та появою нагальної потреби в них з боку не лише природничих, але й соціально-гуманітарних наук. Від кустарної індивідуальної розробки було зроблено значний крок до видання електронної навчальної продукції та іiі використання у практиці вищих навчальних закладів та на освітніх порталах. Зазначається, що розробляється велика кількість електронних підручників із високоякісною гіпермедійною формою представлення учбової інформації, зростає масове виробництво навчальних компакт- 
дисків(CD-ROM), розроблюються web-орієнтовані навчальні системи, ядром яких є електронний підручник [8].

Відповідно до наказу від 01.10.2012 № 1060 «Про затвердження Положення про електронні освітні ресурси», відповідно до Законів України «Про освіту», «Про дошкільну освіту», «Про загальну середню освіту», «Про професійно-технічну освіту», «Про вищу освіту», «Про позашкільну освіту» та на виконання підпункту 48.1 пункту 48 розділу IV Національного плану дій на 2012 рік щодо впровадження Програми економічних реформ на 20102014 роки «Заможне суспільство, конкурентоспроможна економіка, ефективна держава», затвердженого Указом Президента України від 12 березня 2012 року № 187, Державної цільової програми впровадження у навчально-виховний процес загальноосвітніх навчальних закладів інформаційнокомунікаційних технологій «Сто відсотків» на період до 2015 року, затвердженої постановою Кабінету Міністрів України від 13 квітня 2011 року № 494, під електронними освітніми ресурсами (ЕОР) розуміють навчальні, наукові, інформаційні, довідкові матеріали та засоби, розроблені в електронній формі та представлені на носіях будь-якого типу або розміщені у комп'ютерних мережах, які відтворюються за допомогою електронних цифрових технічних засобів і необхідні для ефективної організації навчально-виховного процесу.

В цілому особливістю електронних видань $є$ комплексне поєднання різних форм інформації (графічної, текстової, звукової, відео) та їх виконання на будь-яких електронних носіях - магнітних (магнітна стрічка, магнітний диск), оптичному (CDROM, DVD, CD-R, CD+ та ін.) або публікація у комп'ютерних мережах. Якщо електронне видання має навчальне призначення, то воно має містити систематизований матеріал у відповідній науковопрактичній галузі знань, забезпечувати творче опанування студентами знань, умінь та навичок у цій галузі. Запорукою якості е-навчального видання $\epsilon$ високий рівень виконання та художнього оформлення, повнота інформації, якісний методичний та технічний інструментарій, наочність, логічність та послідовність викладення інформації [7].

Використання ЕОР у навчально-виховному процесі допускається після проведення науковометодичної експертизи та отримання відповідного документа згідно із Порядком надання навчальній літературі, засобам навчання і навчальному обладнанню грифів та свідоцтв Міністерства освіти і науки України, затвердженим наказом Міністерства освіти і науки України від 17 червня 2008 року № 537, зареєстрованим у Міністерстві юстиції України 10 липня 2008 року за № 628/15319. Зберігання, поширення, забезпечення доступу до ЕOP та їхніх описів здійснюється за допомогою їх тиражування на фізичних носіях інформації, а також шляхом їх розміщення в електронних депозитаріях, які надають вільний (у технічному та правовому планах) доступ до ЕОР усім учасникам навчально-виховного процесу, а також на інших локальних і мережевих інформаційних ресурсах.
Актуальною вимогою сучасної парадигми освіти $\epsilon$ створення, апробація та широке застосування у навчальному процесі електронних навчальних видань, які мають навчально-методичне призначення та використовуються для забезпечення навчальної діяльності студентів і вважаються одним із головних елементів інформаційно-освітнього середовища. Зазвичай це підручники з найбільш поширених навчальних курсів: інформатика, іноземна мова, маркетинг тощо. Практично відсутні електронні навчальні матеріали 3 вузькоспеціалізованих навчальних курсів. Це змушує викладачів створювати електронні навчальні матеріали самотужки.

Навчальний матеріал підручника повинен бути сформований у тематичні модулі і висвітлювати питання, передбачені затвердженою робочою програмою. Може включати словник термінів та понять (глосарій), мультимедійні блоки (flash-анімації, відеофрагменти, звукові ряди). Контролююча складова реалізується через перелік питань для самоконтролю та інтерактивного тестування.

Метою їх створення є модернізація освіти, змістове наповнення освітнього простору, забезпечення рівного доступу учасників навчально-виховного процесу до якісних навчальних та методичних матеріалів незалежно від місця їх проживання та форми навчання. Як і друковані навчально-методичні видання, електронні мають відповідати вимогам стандартів і законів України, програмі з навчальної дисципліни; зображення і тексти не повинні порушувати авторські права. Використання інтерактивних комп'ютерних програм активізує усі види діяльності людини - розумову, мовну, фізичну, перцептивну, що прискорює процес засвоєння матеріалу.

Серед переваг електронних навчальних видань слід виділити наступні: вагомі дидактичні переваги електронної книги порівняно з традиційною: технологія мультимедіа створює навчальне середовище 3 яскравим і наочним поданням інформації, що особливо приваблює; здійснюється інтеграція значних обсягів інформації на єдиному носіі; гіпертекстова технологія завдяки застосуванню гіперпосилань спрощує навігацію і надає можливість вибору індивідуальної схеми вивчення матеріалу; технологія інтелектуальних навчальних систем на основі моделювання процесу навчання доповнює підручник тестами, відслідковує і направляє траєкторію вивчення матеріалу, здійснює, таким чином, зворотний зв'язок.

Однією із серйозних проблем є взаємодія між автором змістової частини, редактором та програмістом. Складність полягає в тому, що автор і редактор часто не мають цілісного уявлення про можливості комп'ютерних технологій, а програміст зазвичай не $\epsilon$ фахівцем $з$ предметної галузі створюваного навчального видання [9].

Серед найбільш поширених наукових визначень можна виділити наступні:

- електронний підручник;

• електронний навчальний посібник;

• електронний посібник.

Електронний підручник має декілька дефініцій, серед яких можна виділити наступні: 
- підручник, який існує у форматі електронного документа, тобто у вигляді тексту, який зберігається у пам'яті комп'ютера, може бути прочитаний тільки на екрані спеціального пристрою відображення інформації (монітору) та оброблений тільки за допомогою комп'ютера;

- універсальний інтерактивний гіпермедійний методичний і дидактичний підручник, який містить широке коло питань $з$ тем однієї дисципліни (або різних навчальних дисциплін), викладених у компактній формі гіпертекстового середовища, і призначений для використання у навчальному процесі [10];

- містить систематизований матеріал з відповідної науково-практичної галузі знань, який повністю відповідає програмі дисципліни, створений на високому науковому і методичному рівні, а також відрізняється повнотою інформації, якістю методичного інструментарію, якістю технічного виконання і художнього оформлення, наочністю, логічністю й послідовністю викладу.

Оптимальне визначення дефініцій електронних навчальних видань надав К.Л.Бугайчук, який розглядав такі їх види [11]:

Електронний підручник - це навчальне електронне видання із систематизованим викладом дисципліни (іiі розділу, частини), в якому рівнозначно і взаємопов'язано за допомогою відповідних програмних засобів існує текстова, звукова, графічна та інша інформація, що забезпечує безперервність i повноту дидактичного циклу процесу навчання, служить для групового, індивідуального або індивідуалізованого навчання, відповідає навчальній програмі й призначене для використання у навчальному процесі.

Електронний навчальний посібник - це навчальне електронне видання, що доповнює або частково (повністю) замінює підручник, у якому рівнозначно i взаємопов'язано за допомогою відповідних програмних засобів існує текстова, звукова, графічна та інша інформація, що забезпечує безперервність i повноту дидактичного циклу процесу навчання, служить для групового, індивідуального або індивідуалізованого навчання, відповідає навчальній програмі й призначене для використання у навчальному процесі.

Електронний посібник - це електронне видання, призначене для допомоги в практичній діяльності чи оволодінні навчальною дисципліною, в якому рівнозначно і взаємопов'язано за допомогою відповідних програмних засобів існує текстова, звукова, графічна та інша інформація, що забезпечує безперервність і повноту дидактичного циклу процесу навчання, служить для групового, індивідуального або індивідуалізованого навчання, відповідає навчальній програмі (iі частині) і призначене для використання в навчальному процесі $[11,7]$.

Електронні навчальні видання, зокрема, епідручник, є необхідними для самостійної роботи студента, оскільки вони полегшують розуміння досліджуваного матеріалу, адаптуються відповідно до потреб студента, рівня його підготовки, інтелектуальних можливостей i амбіцій, звільняють від громіздких обчислень і перетворень, тим самим дозволяючи зосередитися на суті предмета, надають більше можливостей для самоперевірки, надають практично необмежену кількість роз'яснень, повторень, підказок.

Електронний підручник акумулює в собі основні навчально-методичні матеріали, необхідні викладачам для підготовки і проведення усіх видів і форм занять відповідно до нормативних вимог. Крім того, він надає широкі можливості для самостійного вивчення навчальних тем, підготовки до занять і одержання додаткової інформації з конкретної навчальної дисципліни. Електронний підручник допомагає студентам здійснювати самоконтроль засвоєння матеріалів з навчальної дисципліни, а викладачам об'єктивно здійснювати поточний і підсумковий контроль успішності студентів.

Крім того, електронні навчальні видання є зручними для викладача, оскільки вони дають змогу виносити на лекції і практичні заняття матеріал на власний розсуд, можливо, менший за обсягом, але найбільш істотний за змістом, залишаючи для самостійної роботи з електронним підручником те, що не увійшло до аудиторних занять; звільняють від перевірки домашніх завдань, типових розрахунків і контрольних робіт за рахунок використання комп'ютера; надають можливість оптимізувати співвідношення кількості та змісту прикладів і завдань, розглянутих під час аудиторних занять та заданих додому; дозволяють індивідуалізувати роботу зі студентами, особливо в частині, що стосується домашніх завдань і контрольних заходів [12].

Електронний підручник визначають як автоматизовану навчальну систему, яка містить дидактичні, методичні, інформаційно-довідкові матеріали 3 навчальної дисципліни, а також програмне забезпечення, що дозволяє комплексно використовувати їх для самостійного одержання і контролю знань [12].

У навчальному процесі за допомогою електронного підручника користувач може: одержати дані про навчальну програму і тематичний план навчальної дисципліни, логіку вивчення тем і послідовність занять; проводити усі форми і види занять із навчальних дисциплін гуманітарного профілю, застосовуючи комп'ютерну техніку; переглянути, вивчити чи повторити навчальний, методичний та інформаційний матеріал; наочно демонструвати (на дисплеї комп'ютера чи на екрані) дидактичний матеріал i наочність (схеми, малюнки, таблиці, графіки, текст), що сприяє його образній подачі і значно підвищує ефективність сприйняття i засвоєння навчальної інформації; здійснити в автоматичному режимі самоконтроль (з виставлянням оцінок) засвоєння змісту навчальних тем і дисципліни в цілому, а також одержати рекомендації 3 додаткового вивчення недостатньо засвоєних навчальних тем; одержати інформацію про рекомендовану навчальну, наукову i методичну літературу; роздрукувати (а за необхідності і допрацювати) типові плани проведення занять і методичні розробки з усіх тем і видів занять; розмножити матеріали для роздачі студентам (плани, таблиці, завдання тощо), необхідні для проведення занять; мати доступ до різноманітних баз даних; індивідуально одержати методичні рекомен- 
дації щодо проведення тих чи інших форм навчальних занять; одержати дані про деякі інформаційні технології, які можна застосувати в освітньому процесі.

Крім того, електронний підручник дає змогу автоматизувати функції поточного і підсумкового контролю знань, що мінімізує суб'єктивний фактор в оцінці знань студентів. А це неминуче підвищить об’єктивність персональних оцінок, що виставляються студентам на екзаменах (заліках), і збільшить продуктивність контрольних функцій викладача. Оцінюючи індивідуальні знання, електронний підручник здатний в автоматичному режимі персонально давати деякі методичні рекомендації студентам, що особливо важливо для самостійного засвоєння матеріалів навчальної дисципліни.

Електронний підручник - це складний механізм, при розробленні та використанні якого виникає низка проблем. Переважну частину 3 них можна подолати за умови проведення стандартизації електронних навчальних видань. Задля цього необхідно здійснити ряд заходів:

- розробити єдині вимоги та рекомендації до спеціалізованого програмного, дидактичного і методичного забезпечення електронного навчання;

- вдосконалити інструментарій, орієнтований на створення електронних засобів навчального призначення, та забезпечити його доступність для викладачів;

- сформувати єдине інформаційне середовище безперервної освіти зі створенням баз даних за напрямами та спеціальностями підготовки фахівців, які включали б у себе методичну документацію, енциклопедичні та довідкові видання, підручники та навчальні посібники, а також допоміжні видання, що використовуються у навчальному процесі.

Створення електронного підручника вимагає дотримання певних принципів, серед яких виділяються наступні:

Принцип розподілення навчального матеріалу. Навчальний матеріал подається структуровано, невеликими, завершеними змістовно модулями. Модулі, крім текстової інформації, повинні супроводжуватися візуалізацією, яка спрямована на розуміння та запам'ятовування матеріалу (принцип наочності).

Важливим є забезпечення можливості для користувача самостійно обирати порядок перегляду інформації - принцип регулювання взаємодії з навчальним матеріалом.

Кожний модуль складається 3 теоретичного матеріалу, контрольних питань/тестів, прикладів. Обов'язковим $\epsilon$ включення вправ та завдань для самостійного розв'язування, контекстних довідок та коментарів (принцип повноти).

Модулі підручника повинні бути пов'язані між собою гіперпосиланнями, щоб користувач міг вільно переходити від одного до іншого - принцип розгалуження. Взагалі, зручна та зрозуміла навігація один 3 ключових елементів електронного підручника, який забезпечує поступове та системне вивчення предмета.
Принцип інтерактивності навчального матеріалу дозволяє користувачу стати активним учасником навчального процесу, оскільки видача інформації відбувається внаслідок його дій. За умови включення у підручник (посібник) елементів автоматизованого тестування користувач може перевірити рівень засвоєння знань, отримавши миттєву оцінку. Доцільним є структурування матеріалу за рівнями складності та встановлення можливості засвоєння матеріалу поступово - від простого до складного. Інтерактивність підручника дозволяє реалізувати ще один важливий принцип - адаптивності до індивідуальних особливостей користувача. На підставі оцінювання та корекції контрольного зрізу підручник має допускати індивідуальну адаптацію користувача до засвоєння навчального матеріалу.

Обов'язковим $є$ розроблення електронного підручника на підставі принципу мультимедійного подання навчальної інформації. Саме використання мультимедійних елементів дозволяє максимально врахувати індивідуальні особливості сприйняття інформації, що є надзвичайно важливим при опосередкованій передачі навчального матеріалу від викладача до студента, яка відбувається в електронному навчанні.

Принцип інтегрованості. Формат електронного підручника (посібника) повинен дозволяти легко доповнювати його модулями, змінювати, інтегрувати у різні інформаційно-навчальні середовища. В ідеалі необхідно прагнути розробки таких електронних засобів навчального призначення, які створювали б одне комп'ютерне середовище для учнів, студентів, викладачів та будь-кого з бажаючих, як в аудиторії, так і вдома.

Враховуючи комплексність та складність такого явища, як електронний підручник, зазначимо, що на сьогоднішній день немає однозначного визначення його дефініції. Ситуацію ускладнює відсутність належної нормативної регламентації цього явища. Певні корективи у термінологію вніс новий стандарт - ДСТУ 7157:2010 «Інформація та документація. Видання електронні. Основні види та вихідні відомості», що набрав чинності з 01 липня 2010 p.

У зазначеному стандарті визначено наступні терміни:

- електронне видання - це електронний документ, який пройшов редакційно-видавниче опрацювання, має вихідні відомості й призначений для розповсюджування в незмінному вигляді;

- електронний аналог друкованого видання електронне видання, що в основному відтворює відповідне друковане видання, зберігаючи розташування на сторінці тексту, ілюстрацій, посилань, приміток тощо;

- електронний документ - документ, інформація в якому подана у формі електронних даних $\mathrm{i}$ для використовування якого потрібні засоби обчислювальної техніки [11].

Види електронних навчальних видань розглядаються наступним чином.

Електронний навчальний посібник - навчальне електронне видання, використання якого доповнює або частково замінює підручник. 
Електронний підручник - електронне навчальне видання із систематизованим викладом дисципліни (iі розділу, частини), що відповідає навчальній програмі.

Електронні методичні матеріали - електронне навчальне або виробничо-практичне видання роз'яснень $з$ певної теми, розділу або питання навчальної дисципліни з викладом методики виконання окремих завдань, певного виду робіт.

Курс дистанційного навчання - інформаційна система, яка $\epsilon$ достатньою для вивчення певних навчальних дисциплін за допомогою опосередкованої взаємодії віддалених один від одного учасників навчального процесу у спеціалізованому середовищі, яке функціонує на базі сучасних психологопедагогічних та інформаційно-комунікаційних технологій.

Електронний лабораторний практикум - інформаційна система, що є інтерактивною демонстраційною моделлю природних і штучних об'єктів, процесів та їх властивостей із застосуванням засобів комп'ютерної візуалізації.

Електронний аналог друкованого видання - електронне видання, що в основному відтворює відповідне друковане видання, зберігаючи розташування на сторінці тексту, ілюстрацій, посилань, приміток тощо.

Електронні дидактичні демонстраційні матеріали - електронні матеріали (презентації, схеми, відео- й аудіозаписи тощо), призначені для супроводу навчально-виховного процесу.

Комп'ютерний тест - стандартизовані завдання, представлені в електронній формі, призначені для вхідного, проміжного і підсумкового контролю рівня навчальних досягнень, а також самоконтролю та / або такі, що забезпечують вимірювання психофізіологічних і особистісних характеристик випробовуваного, обробка результатів яких здійснюється за допомогою відповідних програм.

Електронний словник - електронне довідкове видання упорядкованого переліку мовних одиниць (слів, словосполучень, фраз, термінів, імен, знаків), доповнених відповідними довідковими даними.

Електронний довідник - електронне довідкове видання прикладного характеру, в якому назви статей розташовані за абеткою або в систематичному порядку.

Електронна бібліотека цифрових об'єктів - набір електронних освітніх ресурсів різних форматів, в якому передбачено можливості для іх автоматизованого створення, пошуку і використання.

Застосування електронних підручників стимулює удосконалення організації і методики проведення занять на двох основних напрямках. Перший напрямок пов'язаний 3 розвитком традиційних форм i методів викладання на основі можливостей електронного підручника. Другий напрямок характеризується пошуком принципово нових форм організації і проведення занять, адекватних його перевагам [9].

Для закладу вищої освіти необхідність створення електронної бібліотеки визначається необхідністю вирішення проблеми інформаційної недостатно- сті та збереження інформаційних ресурсів бібліотеки на традиційних паперових носіях.

Так, фонд бібліотеки Криворізького педагогічного інституту на 1 січня 2013 р. складав 610664 прим., 3 них електронних документів - 518 прим. Електронні видання формують фонд електронної бібліотеки,більшість 3 них - це електронні додатки до книг та періодичних видань. За 2012 рік фонд бібліотеки поповнився на 3473 примірники. Електронні видання складають приблизно 0,05 \% бібліотечних надходжень ЗВО [13].

Водночас, цікавими є дані американських дослідників, отримані 2014 року рід час вивчення масштабів використання електронних навчальних посібників студентами американських вишів, які свідчать про те, що серед студентів, які навчаються на денному відділенні майже половина (45\%) регулярно користувалася електронними посібниками, у той час, коли студенти неочної форми навчання надавали перевагу звичному формату [4].

Склад повнотекстового електронного ресурсу розкривається в електронному каталозі (ЕК) бібліотеки у вигляді бібліографічних записів, що включають також посилання на повний текст документу. Важливою складовою цієї роботи $\epsilon$ переведення зберігання повнотекстових документів з локального в мережевий режим, що забезпечує оперативний доступ до них та ефективне управління архівом.

ВИСНОВКИ. Отже, беручи до уваги усе зазначене вище, може дійти наступних висновків. Воперше, одним із вирішальних чинників модернізації системи освіти є створення нового покоління засобів навчання, які поєднували б досягнення сучасної педагогічної науки з потужним дидактичним потенціалом інформаційних технологій. По-друге, саме електронні навчальні видання дають змогу викласти навчальний матеріал із використанням багатого арсеналу різних форм подання інформації та забезпечує неперервність і повноту дидактичного циклу: надає теоретичні знання, забезпечує контроль їх рівня, а також інформаційно-пошукову діяльність.

Таким чином, на нашу думку, електронний підручник повинен, зберігаючи всі можливості звичайних підручників, мати принципово нові, у порівнянні з ними, якості, що включають елементи гіпермедіа і віртуальної реальності, що забезпечують високий рівень наочності, ілюстративності і високу інтерактивність, забезпечувати нові форми структурованого подання більших обсягів інформації і знань [14]. Тож, українським науковцям слід звернути особливу увагу на такий досі ще не дуже типовий для нас та поширений у сфері освіти формат навчального видання, як електронне навчальне видання, яке дозволяє здійснювати навчальний процес на значно вищому рівні i, у свою чергу, сприяє підвищенню мотивації навчання.

\section{ЛІТЕРАТУРА}

1. Бессараб А. О., Антоненко I. Ю. Функції навчального видання в системі комунікацій вищої школи України [Електронний ресурс]. Український інформаџійний простір : науковий журнал Інституту журналістики і міжнародних відносин Київ- 
ського національного університету культури і мистеитв. Гол. редактор М. С. Тимошик. К. : КНУКіМ, 2014. Число 2. Режим доступу: http://ijimv.knukim.edu.ua/zbirnyk/2_1/6-

Bessarab_Antonenko.pdf

2. Ковба Ж. М. Проблеми випуску та поширення навчальної вишівської книги. Бібліотекознавство. Документознавство. Інформологія : науковий журна. Міністерство культури і мистецтв України. Київ : Державна академія керівних кадрів культури i мистецтв. 2010. N 2. С. 62-66.

3. Abd Mutalib Embong, Azelin M Noor, Hezlina M Hashim, Razol Mahari Ali, Zullina H Shaari ( 2012 ), E-Books as textbooks in the classroom Procedia, Social and Behavioral Sciences, Vol. 47, p. 1802 - 1809 https://www.sciencedirect.com/science/article/pii/S1877 042812026390 .

4. Aimee deNoyelles, John Raible, Ryan Seilhamer (2017), Exploring Students' E-Textbook Practices in Higher Education https://er.educause.edu/articles/ 2015/7/exploring-students-etextbook-practices-inhigher-education

5. Бессараб А. О. Оцінювання якості навчальних видань для вищої школи [Електронний ресурс]. Держава та регіони. Серія: Гуманітарні науки. 2013. № 2-3 . Режим доступу: http://nbuv.gov.ua/ UJRN/drgn_2013_2-3_22

6. Щука Г. П. Навчально-методичне забезпечення процесу підготовки фахівців з туризму. Вісник Луганського національного університету ім. Т. Шевченка. 2011. №14(225). С.131-137.

7. Ващук Ф. Г., Ващук О. М. Технологія створення інтерактивних електронних підручників. $M i$ жнародний науковий вісник: збірник наукових статей за матеріалами ХХІУ міжнародної науковопрактичної конферениії, Ужгород - Кошице - Мішкольц, 21-24 травня 2013 року / ред. кол. Ф. Г. Ващук (голова), Х. М. Олексик, І. В. Артьомов та ін.. Ужгород : ДВНЗ «УжНУ», 2013. Вип.7(26). 440 с. С. 33-42.

8. Балыкина Е. Н. Сущностные характеристики электронных учебных изданий (на примере социально-гуманитарных дисциплин) [Електронний ресурс]. Круг идей: Электронные ресурсы исторической информатики: науч. тр. VIII конф. Ассоциации
«История и компьютер» / Московс. гос. ун-т, Алтай. гос. ун-т; под ред. Л. И. Бородкина [и др.]. М. Барнаул, 2003. Режим доступу: http://elib.bsu.by/bitstream/123456789/16384/4/Balykin a_KI.pdf

9. Тимошик М. С. Методика підготовки до друку текстів для наукових, науково-популярних, довідкових та навчальних видань [Електронний ресурс]. Режим доступу : http: //journlib.univ.kiev.ua/ index.php?act=article \&article $=1185$

10. Кононець Н. В. Аспекти педагогічної майстерності викладача: розробка електронних підручників [Електронний ресурс]. Витоки педагогічної майстерності : зб. наук. прац̧ь. 2009. № 6. С. 202-210. Режим доступу: www.nbuv.gov.ua/ portal/Soc_Gum/Vpm /2009_6/.

11. Бугайчук К. Л. Електронний підручник: поняття, структура, вимоги [Електронний ресурс]. Інформаційні технології і засоби навчання. 2011. № 2 (2011). Режим доступу до журн.: http://journal.iitta.gov.ua/index.php/itlt/issue/view/41\#. UiMDDDbIY1Q

12. Соха М. В. Мониторинг эффективности использования електронних изданий в научной библиотеке ВУЗа. Сучасні тенденції розвитку бібліотеки в структурі інформачійного забезпечення навчального процесу $і$ наукової діяльності ВНЗ: матеріали науково-практичної конферениіі / [уклад.: Н. В. Мороз, Г. В. Макаренко]. Чернігів : Наукова бібліотека ЧНТУ, 2014. 80 с. С. 58-67.

13. Кравченко Олена. Комплектування фонду бібліотеки ВНЗ у сучасних умовах (з досвіду роботи бібліотеки Криворізького педагогічного інституту ДВНЗ «Криворізький національний університет») [Електронний ресурс]. Вісник Львівського ун-ту. Серія книгозн. бібліот. та інф. технол. 2014. Вип. 9. С.211- $215 . \quad$ - Режим доступу http://library.lnu.edu.ua/bibl/images/Vudanna_WEB_pd f/1Visnuk_NB/2014_Vupysk_IX/211-215.pdf

14. Лізвінський В. Л. Генеза нормативних вимог до змісту вузівського підручника (друга половина $\mathrm{XX}$ ст. - початок XXI ст.) [Електронний ресурс]. Режим доступу: http:// www.nbuv.gov.ua/ portal/soc_gum/pfto/2010_7/files/PD710_26.pdf

\section{ELECTRONIC EDUCATIONAL PUBLICATION AS A NEW FORMAT OF PROVIDING EDUCATIONAL PROCESS IN ESTABLISHMENT OF HIGHER EDUCATION}

\section{Bigdan, R. Kantemyrova, O. Kondrashova, O. Reznichenko}

Kremenchuk Mikhailo Ostrohradskyi National University

vul. Pershotravneva, 20, Kremenchuk, 39600, Ukraine. E-mail: kantemyrovarm@gmail.com

Purpose. The purpose of the article is to study features of electronic educational publications as a kind of modern educational publications for institutions of higher education, to analyze publication of educational literature for institutions of higher education in Ukraine, to highlight the problems and preconditions for development of educational publications for institutions of higher education at the present stage, and the state of this issue nowadays. Methodology. The complex nature of the research subject and the heterogeneity of modern educational publications have led to the integration of a number of scientific methods. In addition to general scientific methods of research, special methods have been used. So, the method of system analysis has allowed exploring the material fully and thoroughly. With the help of the typological method, varieties of modern electronic educational publications have been defined and characterized. The theoretical methods used during the study include the following: analysis and synthesis; induction and deduction; comparison; classification; abstraction; generalization. The empirical method is presented in analyzing documents and products of publication activity. Results. The need for a systematic and comprehensive study of modern electronic educational publications for institutions of higher education, their functional features, specifics of design, makes a num- 
ber of requirements for the structure and content of electronic educational publications for institutions of higher education and the conditions for their implementation. Originality. An attempt was made to conduct a comprehensive study of modern electronic educational publications for institutions of higher education. Practical value. Materials and results obtained can be used in university courses on the theory of publishing and editing, editorial and publishing specialty, in extracurricular activity. The material presented can be applied during writing course papers, in elective and practical classes devoted to problems of editing and publishing of educational publications.

Key words: educational publications, e-learning publications, institutions of higher education, electronic educational resources (EOR).

\section{REFERENCES}

1. Bessarab, A. O., Antonenko, I. Yu. (2014), Functions of the educational edition in the system of communications of the higher school of Ukraine, Ukrainian information space: scientific journal of the Institute of Journalism and International Relations Kyiv National University of Culture and Arts, Number 2, available: http://ijimv.knukim.edu.ua/zbirnyk/2_1/6Bessarab_Antonenko.pdf

2. Kovba, Zh. M. (2010), Problems of the production and distribution of the educational book, Library Science. Documentation. Informology: Scientific Journal of Ministry of Culture and Arts of Ukraine, Vol. 2, p. 62-66.

3. Embong, Abd Mutalib, Noor, Azelin M., Hashim, Hezlina M., Razol, Mahari Ali, Zullina, H Shaari ( 2012 ), E-Books as textbooks in the classroom Procedia, Social and Behavioral Sciences, Vol. 47, p. 1802 - 1809 https://www.sciencedirect.com/science/article/pii/S1877 042812026390 ,

4. De Noyelles, Aimee, Raible, John, Seilhamer, Ryan (2017), Exploring Students' E-Textbook Practices in Higher Education https://er.educause.edu/articles/2015/7/exploringstudents-etextbook-practices-in-higher-education

5. Bessarab, A. O. (2013), Evaluation of quality of educational publications for higher education, State and regions. Series: Humanities, Iss. 2-3, available: http://nbuv.gov.ua/UJRN/drgn_2013_2-3_22

6. Shchuka, G. P. (2011), Educational and methodological support of the process of preparation of specialists in tourism, Visnyk of Lugansk National University named after T. Shevchenko, Iss. 14 (225), p.131-137.

7. Vaschuk, F. G., Vaschuk, O. M. (2013), Thetechnology of creation of interactive electronic textbooks, International scientific bulletin: collection of scientific articles on the materials of XXIUth International scientific-practical conference, Uzhgorod - Kosice - Miskolc, May 21-24, 2013,p. 33-42.
8. Balykina, E. N. (2003), Essential characteristics of electronic educational publications (on example of social and humanitarian disciplines), Circle of ideas: Electronic resources of historical informatics: scientific. tr VIII conference Association "History and Computer», Moscow. State Unt Altay. state un-t, available:http://elib.bsu.by/bitstream/123456789/16384/ 4/Balykina_KI.pdf

9. Timoshik, M. S. Method of preparation for the printing texts for scientific, popular scientific, reference and educational publications, available: http: //journlib.univ.kiev.ua/index.php? act=article $\&$ article $=1$ 185

10. Kononets, N. V. (2009), Aspects of pedagogical mastery of the teacher: development of electronic textbooks, Origins of pedagogical skill: Col. Sciences works, Vol. 6, p. 202-210.

11. Bugaychuk, K. L. (2011), Electronic textbook: concept, structure, requirements, Information technologies and teaching means, Vol. 2, available http://journal.iitta.gov.ua/index.php/itlt/issue/view/41\#. UiMDDDbIY1Q

12. Sokha, M. V. (2014), Monitoring the efficiency of the use of electronic publications in the scientific library of university, Modern trends in the development of the library in the structure of the information provision of the educational process and the scientific activity of University: the materials of the scientific and practical conference, Chernigov: Scientific Library of the ChNTU, p. 58-67.

13. Kravchenko, O. (2014), Acquisition of library of higher educational institutions in modern conditions (from the experience of Krivoy Rog Pedagogical Institute KrivoyRog National University), Visnyk of Lviv Univ. Series book. Bible and inf. Technol., Vol. 9, p. $211-215$.

14. Lizvinsky, V. L. (2010), Genesis of normative requirements to the content of the textbook of the university (second half of the twentieth century - the beginning of the XXI century) available: http: // www.nbuv.gov.ua/portal/soc_gum/pfto/_7/files/PD710_ 26.pdf20. 